\title{
Small Business Survival in a Resort Town and Their Views on Location, Marketing, and Challenges of Doing Business
}

\author{
David Lynn Hoffman \\ Metropolitan State University of Denver \\ Cynthia Sutton \\ Metropolitan State University of Denver \\ David Bechtold \\ Metropolitan State University of Denver
}

\begin{abstract}
This research was an exploratory survey of small businesses in Breckenridge Colorado to determine how important location was to their businesses, their use of traditional marketing, and their challenges surviving in a resort town. The survey covered a variety of businesses and found that the group of retail, entertainment, and food services was very reliant on tourism and therefore very concerned about their location. This group's mean reliance on tourism was higher than the sample mean. The results are not surprising, but they do emphasize this group's focus on location. The results need to be verified with a larger sample size or the use of small sample methods. What was surprising was this group's use of not just location but a mix of traditional marketing and advertising techniques to gain customer recognition. Also surprising were their comments that survival in a resort town was challenging given internet competition, the difficulty of finding and retaining motivated employees, and the myriad of government regulations they faced.
\end{abstract}

Keywords: location, marketing, challenges of running a business, society value of small businesses

\section{INTRODUCTION}

The research surveyed 32 small businesses in Breckenridge Colorado to determine their dependence on location, their use of traditional marketing and their challenges surviving. The survey used a series of 32 questions about their experience, business experience, and reliance on tourism, and marketing. To determine their reliance on location, the distance from their front door to the edge of the sidewalk on main street was calculated.

\section{LITERATURE REVIEW ON LOCATION}

Most large and small retail, food, and entertainment business are careful about their location decisions. For many, location is critical for their survival (Brooks, 2009; Jardon, 2018; Vlachou and Iakovidou, 2015; 
Montgomery, 2003; Wendt, 19720. Larger organizations have access to sophisticated complex algorithms to determine proper locations for their stores (Harris, Webber and Sleight, 2005: Phelps and Wood, 2018; Weber and Chapman, 2011, Carver, 1991; Dhingra, Singh and Sinha, 2009; Galbraith, DeNoble and Estavillo, 1990). Some larger organizations use location consultants, consortiums, and complex algorithms to help with location decisions (Weber and Chapman, 2011; Phelps and Wood, 2018).

There is a long history of location analysis (Phelps and Wood, 2018). Phelps and Wood (2018) identified cost, demand, and sales potential as the three principal factors. Some typical analyses use a mix of algorithms based on the typical variables such as: population density, income, education, age, gender, neighborhoods, government regulations, and infrastructure such as travel patterns, and ease of entry and exit into a location (Weber and Chapman, 2011; Kimelberg and Williams, 2013). Some analyses may also include psychographic variables of who makes the buying decisions, what motivates them, why, how often they buy, and what influences them.

The most complex model uses principal component factor analysis with geospatial neighborhood classifications data and then a multicriterial model using an analytical hierarchy process of 41 variables (Weber and Chapman, 2011). The outcome is an easy to read visual map with the location in the center and the degree of that variable's influence shown graphically. This aspect allows users to visually ascertain the importance of each variable and adjust for other iterations. Unfortunately, most small businesses do not understand or have access to these complex location algorithms and rely on foot traffic.

\section{ABOUT BRECKENRIDGE}

Breckenridge is a resort town at 9,600 feet above sea level in Summit County's ten-mile range of mountain peaks. While it is a world known ski resort, it has developed year-round activities. The winter activities include downhill skiing, cross country skiing, snow shoeing, back country skiing, sledding, snow sculpture competitions, and snow mobile rides.

\section{FIGURE 1}

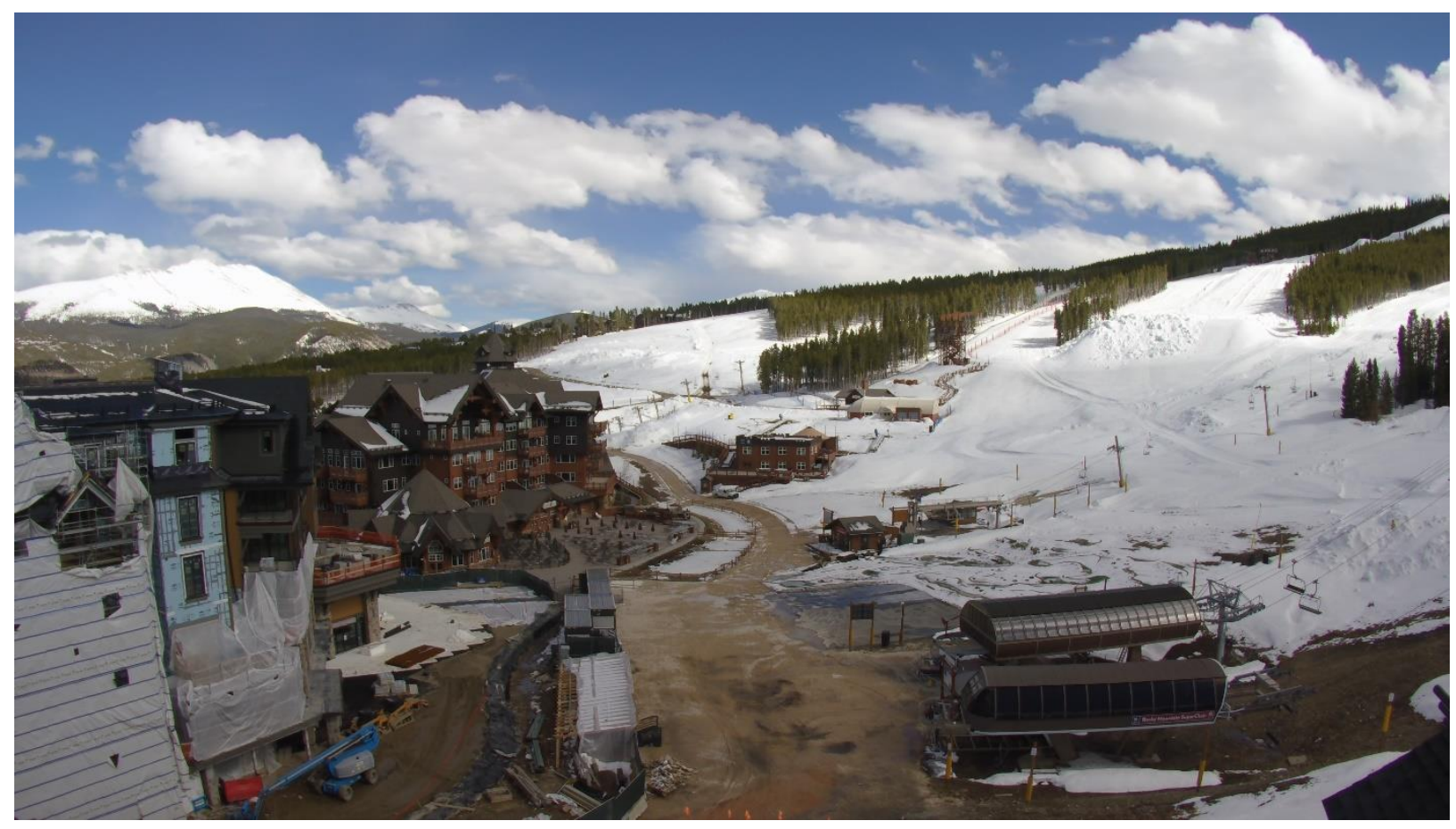


The varied summer activities include National Repertory Orchestra, Breckenridge Music Institute concerts, theater, art exhibitions, hiking, mountain biking, road biking, fly fishing, and mountain hiking with many hiking trails from easy trails to the arduous 14, 265 foot Quandary peak and numerous 13,000 foot peaks. The many trails provide great hiking and unique vistas of the former mining camps. For those so inclined there are many historical sites, historical tours, theater, and art activities (and a fun ghost tour).

\section{FIGURE 2}
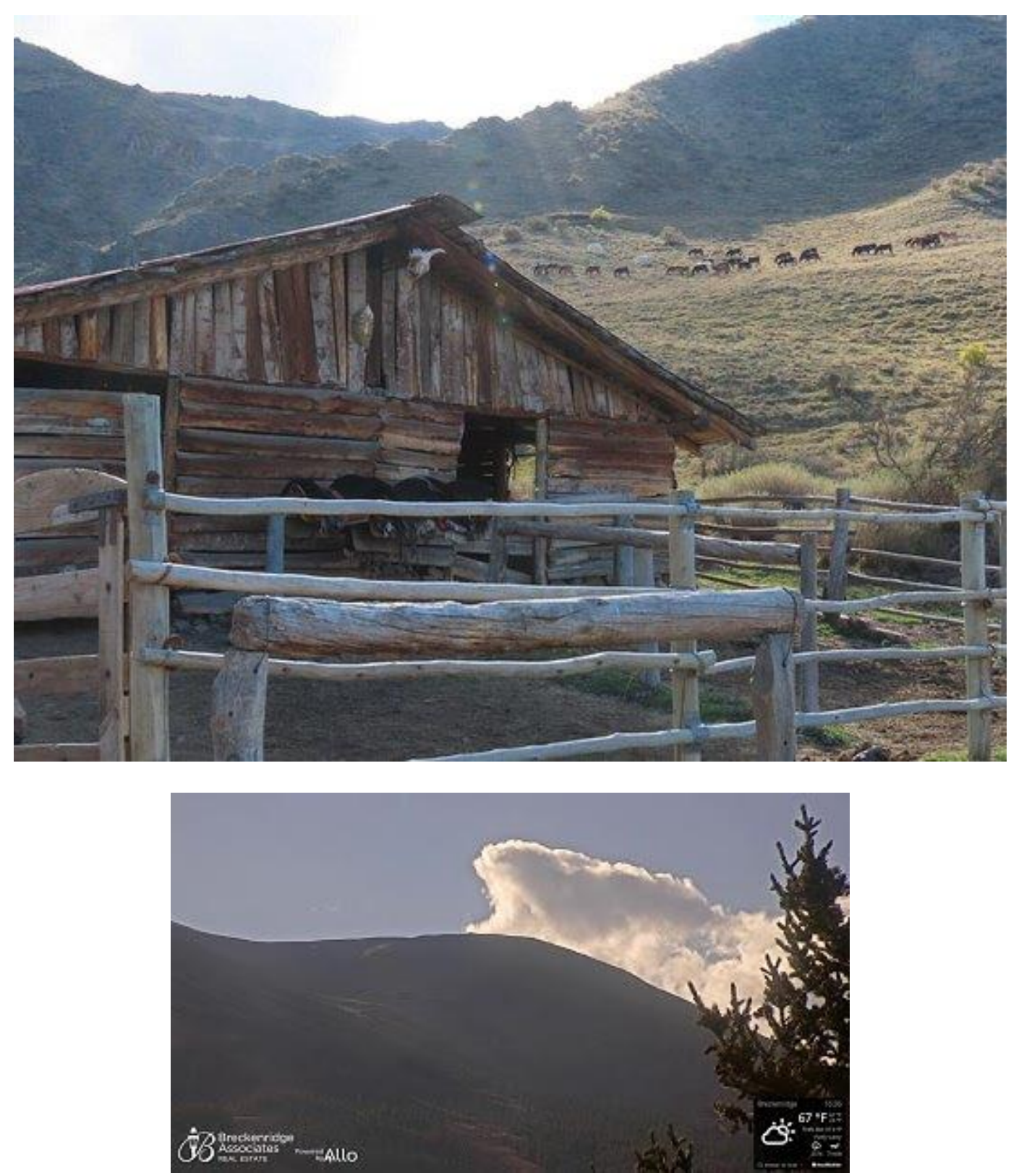

Because of the rich Victorian history as a former mining town the historically protected areas showcase colorfully decorated buildings from the 1880s and 1890s. The planning commission vigorously maintains the historical image of the town. Consequently, the main street is full of tourists walking the 8 blocks from the north to the south. 


\section{METHODOLOGY}

The authors personally interviewed 32 business and asked several demographic and business questions including the respondent's personal business experience, the company's duration in years, and their challenges surviving in a resort town. Each respondent was given sufficient time to complete the survey and personally thanked by the authors. However, given the small sample size, this survey should be viewed as a qualitative exploratory research.

\section{Determining Distance}

All the major foot traffic goes from $350 \mathrm{~S}$. Main to 150 North main in an 8-block area (see map in appendix). This foot traffic is stopped at the south end by the roads to Hoover Pass or Boreas pass and stopped on the north by a light commercial area and Wellington Street. The one block of Ridge Street from $106 \mathrm{~S}$. Ridge to $113 \mathrm{~S}$. Ridge Street also sees heavy foot traffic and complements main street by being one block away. Most of the retail, entertainment, and restaurants are located within these two areas. This group drives the economic health of the town.

The foot traffic in this 8-block area is extremely heavy. The authors counted 330 pedestrians in a onehour period during a nonpeak summer hour. The authors used the west sidewalk because most tourists walk up one side and down the other to view all of the shops.

In the winter, the foot traffic is approximately twice that amount from 4 to $6 \mathrm{pm}$ when skiers return from the mountain into downtown. The Main Street is only one block from the ski gondola which empties at the northern end of the 8-block area and is easily walkable even in ski boots.

For the purposes of this research, the distance in feet of the business to the edge of the main street sidewalk was measured by a combination of smart phones and google maps.

\section{FIGURE 3}

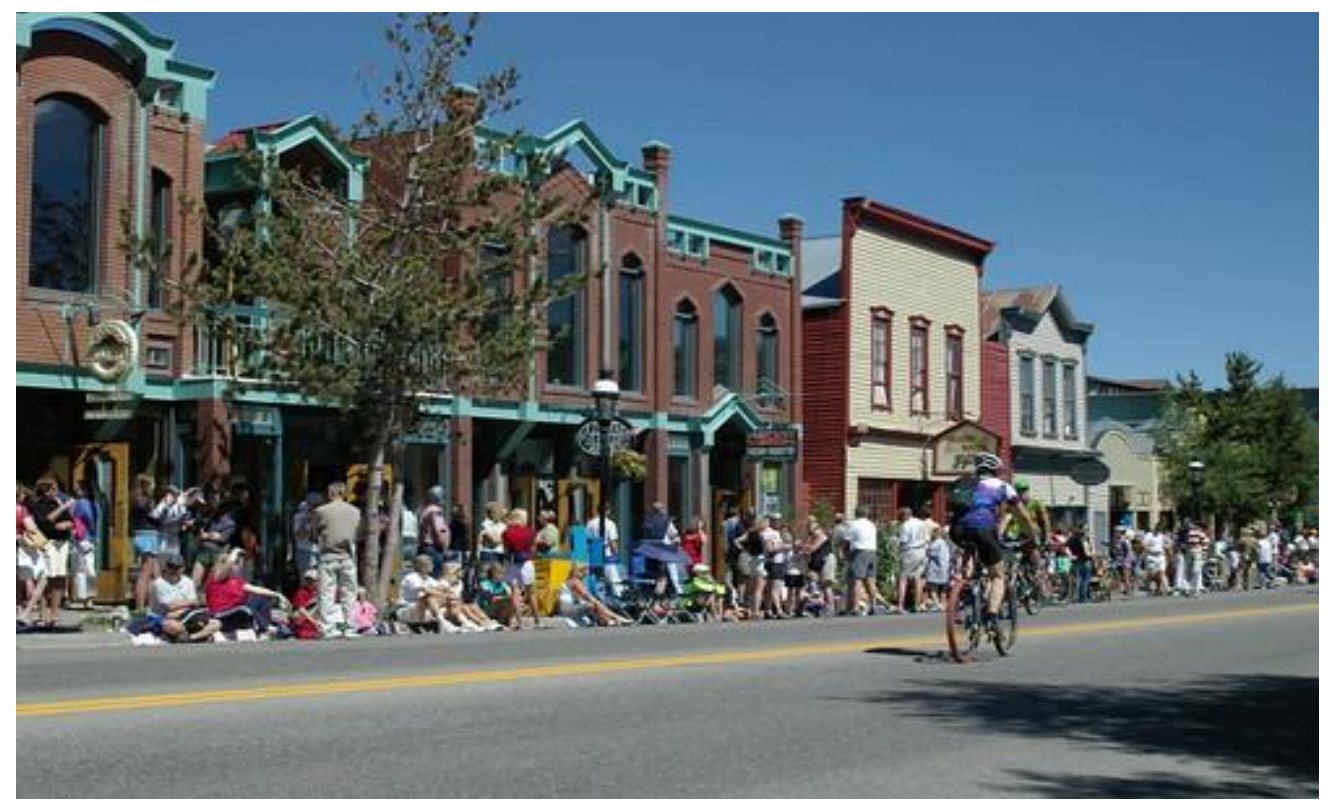

Two question measured that business's reliance on tourism. The first question asked the respondent on a 5-point Likert scale the business's dependence on tourism from 1 low strongly disagree to 5 high or strongly agree. The second question asked the respondent what percentage of the business depended on tourism with five choices: 0 to 20 percent, 21 to 30 percent, 41 to 60 percent, 61 to 80 percent, and 81 to 100 percent.

In addition, the survey collected descriptive data and comments about the challenges in a resort town. 


\section{DESCRIPTION SURVEY RESULTS}

The following describes several descriptive statistics regarding the types of industries in the Breckenridge central business district as well estimated annual revenue levels and reliance on tourism. The final statistics look at the length of time that the business has been operational as well as the business experience that the survey respondent has.

\section{Industry Sector}

Over half of all businesses surveyed (52.2\%) were Retail (34.4\%), Arts and Entertainment (9.4\%) and Accommodations (9.4\%). These industries normally require heavy foot traffic, especially from tourism, so their location in these eight blocks in the central business district was not surprising. What was interesting was the number of industry sectors that would not appear to require heavy foot traffic or tourism to be successful. While further investigation is warranted to determine their motivation, they ultimately depend on the town's attractions.

\section{TABLE 1 INDUSTRY}

\begin{tabular}{ll}
\hline Industry Classification & Percent \\
Retail & 34.4 \\
Real Estate & 18.8 \\
Construction & 15.5 \\
Finance \& Insurance & 12.5 \\
Arts and Entertainment & 9.4 \\
Accommodations & 9.4 \\
\hline
\end{tabular}

\section{Annual Revenue}

Table 2 describes the estimated annual revenue for the surveyed businesses. 58.8\% of the businesses surveyed earned less than $500 \mathrm{~K}$ in estimated annual revenue while $41.6 \%$ of the businesses earned estimated annual revenue in excess of $\$ 500 \mathrm{~K}$. Further research into revenue by business type would help to discern which type of enterprise had been able to achieve large annual revenue and if they were also dependent on heavy foot traffic and tourism to achieve that size.

TABLE 2

\section{APPROXIMATE ANNUAL REVENUE}

\begin{tabular}{ll}
\hline Revenue & Percent \\
0 & 0 \\
1 to $\$ 25.000$ & 0 \\
$\$ 26,000$ to $\$ 50,000$ & 4.2 \\
$\$ 51,000$ to $\$ 100,000$ & 8.3 \\
$\$ 101,000$ to $\$ 150,000$ & 8.3 \\
$\$ 151,000$ to $\$ 200,000$ & 4.2 \\
$\$ 201,000$ to $\$ 250,000$ & 4.2 \\
$\$ 251,000$ to $\$ 300,000$ & 4.2 \\
$\$ 300,00$ to $\$ 400,000$ & 8.3 \\
$\$ 401,000$ to $\$ 500,000$ & 16.7 \\
$\$ 501,000$ to 1 million & 20.8 \\
$\$ 1$ million to 2 million & 4.2 \\
$\$ 2$ million to 5 million & 8.3 \\
\$5 million to 10 million & 0 \\
Above $\$ 10$ million & 8.3 \\
\hline
\end{tabular}




\section{Importance of Tourism in the Local Economy}

Table 3 describes an estimate of how much revenue is generated by tourism into Breckenridge and the central business district. Based upon this survey, tourist revenue generated $40 \%$ or more of the annual revenue in 7 out of 10 of these businesses. In a separate question, when asked about the importance of tourism revenue to maintaining the business, all respondents in the retail, arts and entertainment, and accommodations sectors ranked tourism revenue at the highest level of importance (a " 5 " out of a 5-point Likert scale).

Perhaps it is not surprising that the other three industry sectors in the central business district (real estate, construction, and finance and insurance) would not see a direct correlation between their business and tourism activity. Yet all recognize the importance of tourism to the region's general economic health. In this case those industries that rely heavily on tourism could be looked upon as a lead indicator to the future health of the other businesses surveyed and ultimately the economic health of the region.

TABLE 3

RELIANCE ON TOURISM

\begin{tabular}{ll}
\hline Percent of the Business that Rely on Tourism & Percent \\
\hline $0-20 \%$ & 16.7 \\
$21-40 \%$ & 13.3 \\
$41-60 \%$ & 10.0 \\
$61-80 \%$ & 36.7 \\
$81-100 \%$ & 23.3 \\
\hline
\end{tabular}

\section{The Importance of Business Longevity}

In the Breckenridge central business district, 8 out of 10 businesses have been in existence for over 5 years (See Table 4). Even more surprisingly is that $55 \%$ of the businesses surveyed had been in existence for ten years or longer. Further research needs to be conducted into the importance of business brand and reputation in a central business district that is so highly dependent on tourism. Moving forward, correlating business type, years in operation, and average revenue will provide greater focus on the relative importance of the three principal factors on location decision-making: cost, demand, and sales potential as described by Phelps and Wood (2018).

\section{TABLE 4}

YEARS THE COMPANY HAS BEEN IN BUSINESS

\begin{tabular}{ll}
\hline Years in Business & Percent \\
1 to 5 & 20.7 \\
Over 5 to 10 & 24.1 \\
Over 10 to 20 & 27.6 \\
Over 20 & 27.6 \\
\hline
\end{tabular}

\section{Business Experience of the Respondents}

Having an established business with a recognized brand is not sufficient to long-term success. Reputation is the other critical element to maintaining business longevity. In most instances the maintenance of reputation requires experience in maintaining positive customer relationships and exceeding customer expectations. This is especially true in a tourist driven economy when new visitors will often substantially outnumber regulars. In those instances, reputation will drive many first time decisions regarding which locations to visit and which to avoid. In the survey the authors found that 2 out of 3 of the respondents had 5 years or more business experience. Further analysis to correlate business experience with company age and industry classification will add clarity to the importance of location to the success of the business. 
TABLE 5

YEARS OF BUSINESS EXPERIENCE OF RESPONDENT

\begin{tabular}{ll}
\hline Years of Experience & Percent \\
\hline 1 to 5 & 34.6 \\
Over 5 to 10 & 19.2 \\
Over 10 to 20 & 30.8 \\
Over 20 & 15.4 \\
\hline
\end{tabular}

In addition to location many respondents use other forms of advertising and promotion. While in many areas of the US, traditional media are decreasingly used, in this mountain community the local TV, radio, newspapers, and magazines are heavily used by locals and tourists.

TABLE 6

\section{CURRENT REACTIONS TO THE BUSINESS ENVIRONMENT}

\begin{tabular}{lc}
\hline Type of Marketing or Promotion or Sales Force & Percent \\
\hline Public Relations (attending events) & 18.6 \\
Advertising (magazines, radio, TV) & 18.6 \\
Adding new Products/Services & 17.0 \\
Extending Working Hours & 15.3 \\
Promotions (coupons, bundling) & 11.8 \\
Decreasing Sales Force & 6.8 \\
Reducing work hours & 5.1 \\
Increasing Sales Force & 3.4 \\
Using more part-time workers & 1.7 \\
Cutting employee benefits & 1.7 \\
\hline
\end{tabular}

It should be noted that some extended their hours, some reduced their sales staff, and others increased it.

The following shows their use of media advertising. While most still the local newspaper, radio, and TV many are using social media to advertise their hours, reservation systems, and menus.

TABLE 7

USE OF THE FOLLOWING MEDIA FOR THE BUSINESS'S ADVERTISING

\begin{tabular}{ll}
\hline Type of Media Advertising & Percent \\
\hline Social Media & 37.0 \\
Newspaper & 19.5 \\
Radio & 15.2 \\
Magazine & 10.9 \\
TV & 10.9 \\
Outdoor advertising & 6.5 \\
\hline
\end{tabular}

It is encouraging that $75.9 \%$ of the respondents do have some legal structure other than sole proprietor or a general partnership. 
TABLE 8

LEGAL ORGANIZATIONAL STRUCTURE

\begin{tabular}{ll}
\hline Type of Legal Structure & Percent \\
\hline S-Corporation & 38.0 \\
Limited Liability & 24.1 \\
Sole Proprietor & 20.7 \\
C corporation & 13.8 \\
General Partnership & 3.4 \\
Limited Partnership & 0 \\
\hline
\end{tabular}

When asked how easy it is to start a Colorado business on a Likert scale from 1 strongly disagree to 5 strongly agree the mean was 3.03 barely above neutral. When asked if the USA culture supports, encourages, rewards and values small business the mean was 3.36 again barely above neutral.

\section{HYPOTHESES ON LOCATION}

Because most of these businesses depend on tourism, the distance of the business in feet to the main street was measured.

Hypothesis one: The correlation between distance in feet will be negatively correlated with that business's dependence on tourism.

\section{Survey Findings on Location}

The first question using a scale of 1 low to 5 high, had a mean of 3.83 for all the businesses (this included banks, construction, remodelers, insurance companies, and title companies with all the others). However, the mean for just retail, arts, entertainment, and accommodations was 5.00. Their answer meant that all of them were heavily reliant on tourism.

The second location question asked the respondent to specify in categories the percentage of their revenue that depended on tourism. Using all the respondents, 69 percent reported that they had 41 to 100 percent reliance on tourism. The subset of retail, food, entertainment, and accommodations had a mean of 4.5 on the question asking them to rate their reliance on tourism from 1 low to 5 high.

The distance hypothesis had a negative correlation of negative .536 using question one with the distance measurement and a correlation of negative .35 using the second distance question. This suggests that the group of businesses which are dependent on resort foot traffic deliberately pick locations close to the main street traffic flow. Businesses that are less dependent on foot traffic can choose locations farther from this flow. While this seems to confirm the hypothesis, small sample size methods should be used or the study replicated with a bigger sample size.

\section{GREATEST CHALLENGES OF SMALL BUSINESS SURVIVE IN A RESORT TOWN}

\section{Finding and Retaining Motivated Employees}

The challenge of finding and retaining motivated employees is the obstacle most often mentioned by many employers in the US today and especially in this resort town. Previously many Breckenridge employees had to work two or three jobs to survive because of the cost of housing, food, and essentials. Once the Covid-19 shutdown occurred, all the resort dependent employees left. Many left for other jobs, education, or new careers.

After the shutdown lifted, employee housing was drastically impacted from the influx of investors purchasing real estate for short term and vacation rentals. Remaining workers can find cheaper housing in other towns but must drive over mountain roads or passes twice a day often in bad winter weather. 


\section{Competition From the Internet, Big Box Stores and Customers Attitudes}

The second most mentioned challenge was competition from big box stores, the internet, and cheaper alternatives. Although the foot traffic is large, many customers compare Breckenridge prices to what they can find on the internet. The photography shop complained about the ability of novice photographers to take decent, even though lessor quality, photographs with cheaper cameras and phones.

\section{Seasonality}

The third most mentioned challenge was the seasonality of revenue. When the ski area does well with high ski traffic, downtown sales are good. However, during the off seasons which are May to June and September to November, traffic is much lighter. The best seasons are of course winter because of the ski area and middle summer. Summer traffic is also high because Breckenridge has built a great reputation as a summer destination resort with camping, hiking, biking, music festivals, concerts, and other activities.

\section{Government Regulations}

Next most mentioned was government regulations at all levels. This included federal, state, county, and city regulations. As expected, the marijuana shops complained about the laws and government regulation but added the additional difficulty of finding local workers who do not have arrest or conviction records.

As a historical note the Main Street merchants successfully passed a local ordinance moving the marijuana shops away from the downtown. The 'not in my back yard' merchant effort succeeded in removing them from the Main Street. Because marijuana customers are willing to drive an extra 2 miles, the off Main Street location has not affected their businesses.

\section{Other Comments}

Less mentioned were availability of capital and determination of what kind of client the business should serve. Some business such as banks, title companies, law offices and others depend on those businesses who serve customers directly. As expected, this group said their main challenge was developing the former group into clients. The only groups that were ecstatic about their prospects were construction workers who have more work than they can service during this real estate boom.

\section{CONCLUSION}

The results on location were expected especially that the subset relying totally on tourism placed themselves as close as possible to Main Street. An interesting result was the continuing complementary reliance on traditional advertising. As mentioned above, this is understandable given the strength of the local media. Another surprising result was their concern about the difficulty of starting a business in Colorado and their response that there was lack of support for small business in the US. Comments about the challenges of survival often depended on the type of business, their location, and whether they served tourists or other businesses.

\section{ACKNOWLEDGEMENT}

The source of all the pictures are from the Breckenridge website and a draft version of this paper was presented at the Small Business Institute Conference. Subsequently, the paper was rewritten, updated, and expanded. 


\section{REFERENCES}

Brooks, I. (2009). First Impressions make the difference. Business, 23(5).

Carver, S.J. (1991). Integrating multi-criteria evaluation with geographical information systems. International Journal of Geographical Information Science, 5, 321-329.

Dhingra, T., Singh, T., \& Sinha, A. (2009) Location strategy for competitiveness of special economic zones: A generic framework k for India. Competitive Review, 19(4).

Galbraith, C.S., DeNoble, A.F., \& Estavillo, P. (1990). Location criteria and perceptions of regional business climate: A study of Mexican and U.S. Small Electronic Firms. Journal of Small Business Management, 28(4), 34-47.

Harris, R., Webber, R., \& Sleight, P. (2005). Geodemographics, GIS and Neighborhood Targeting. New York: John Wiley and Sons.

Kimelberg, S.M., \& Williams, E. (2013) Evaluation of the importance of business location factors: The influence of facility type. Growth and Change, 44(1), 92-117.

Jardon, C. (2018). Location and competitiveness in subsistence small business. Competitive Review, $38(2), 166-171$.

Vlachou, C., \& Iakovidou, O. (2015). The evolution of studies on business location factors. Journal of Developmental Entrepreneurship, 20(4).

Montgomery, D. (2003). Small Retail Tenacity. Business, 25(4), 1.

Phelps, N.A., \& Wood, A.M. (2018). The business of location: Site selection consultants and the mobilization of knowledge in the location decision. Journal of Economic Geography, 18, 10231044.

Weber, P., \& Chapman, D. (2011) Location intelligence: An innovative approach to business location decision making. Transactions in GIS, 15(3), 309323.

Wendt, P. (1972). Deciding on Location for Small Business. Journal of Small Business Management, $10(1), 1-4$.

\section{APPENDIX}

FIGURE 4

PICTURES AND MAPS OF BRECKENRIDGE

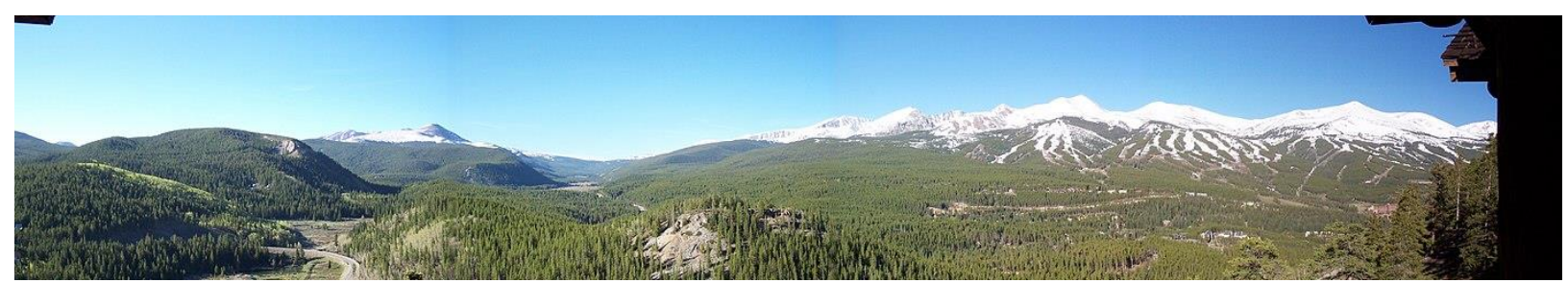

Source: Breckenridge web site with the ski areas shown in the background. 
FIGURE 5

MAP OF MAIN STREET FOOT TRAFFIC FROM MAIN STREET STATION IN THE SOUTH TO WELLINGTON IN THE NORTH

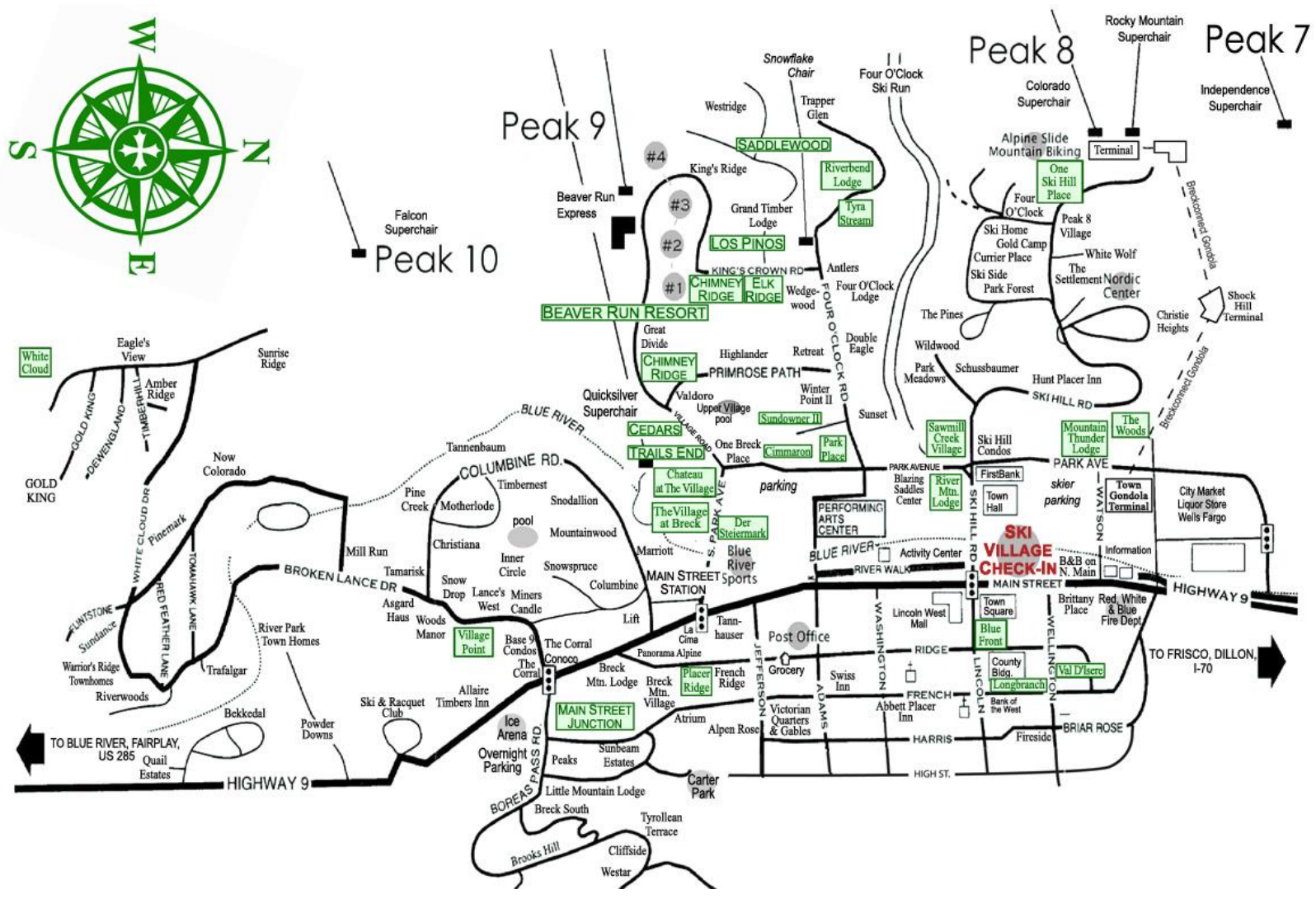

FIGURE 6

PICTURE OF TOURISTS ON MAIN STREET

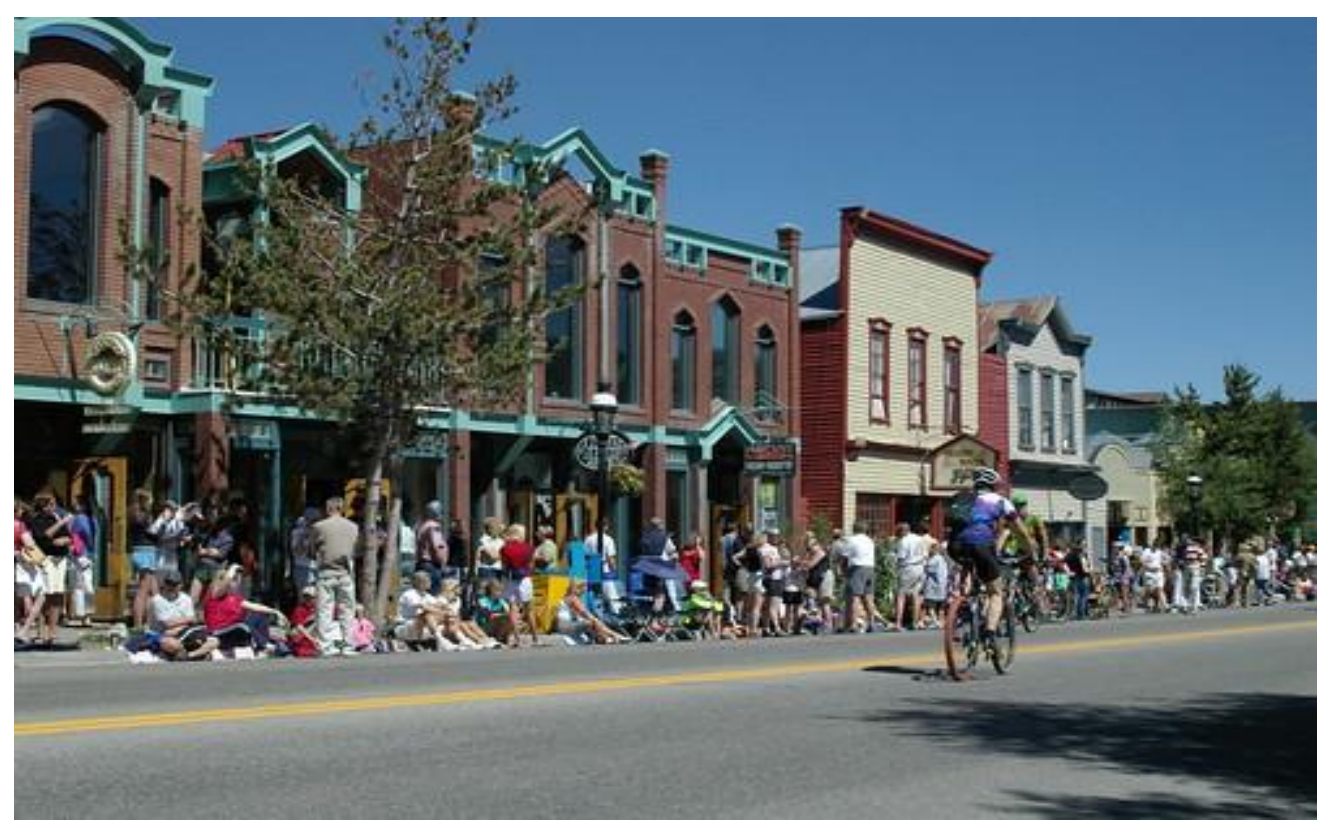

